Article

\title{
Barriers, Risks and Policies for Renewables in the Gulf States
}

\section{Johan Lilliestam ${ }^{\dagger}, *$ and Anthony Patt ${ }^{\dagger}$}

Institute for Environmental Decisions, Climate Policy Group, ETH Zürich, Universitätstrasse 22, 8092 Zürich, Switzerland; E-Mail: anthony.patt@usys.ethz.ch

$\dagger$ These authors contributed equally to this work.

* Author to whom correspondence should be addressed; E-Mail: johan.lilliestam@usys.ethz.ch; Tel.: +41-44-632-6037.

Academic Editor: Vincenzo Dovì

Received: 28 February 2015 / Accepted: 16 July 2015 / Published: 5 August 2015

\begin{abstract}
The countries of the Gulf Cooperation Council (GCC) have both large fossil fuel resources and vast renewable energy potentials. Here, we investigate in a literature meta-analysis and a survey, whether there is a need for renewables in the GCC, what barriers and risks presently deter investments, and what possible policy-solutions could be. We find that there is a long-term need for renewables, to diversify the economy and prepare for a post-fossil fuel era. In the short term, two main obstacles deter investments: inefficient bureaucracy, and the combination of fossil fuel/electricity subsidies and the absence of renewable energy support. Removing fossil fuel and consumption subsidies or introducing a support scheme could make investments in renewables profitable. Eliminating energy subsidies appears particularly beneficial to the economic outlook but this seems particularly difficult to implement, due to the political economy of rentier states. Increased bureaucratic transparency and efficiency is needed, so that potentially attractive investments can rapidly and predictably obtain the necessary permissions. Hence, the administrative and economic environment for renewable energy investments in the GCC is not right today, and no breakthrough is on the horizon, but there is a range of policy solutions to enable investments in the future.
\end{abstract}

Keywords: renewable energy; renewable energy investments; Gulf Cooperation Council (GCC); renewable energy policy 


\section{Introduction}

The countries of the Gulf Cooperation Council (GCC)-Bahrain, Kuwait, Oman, Qatar, Saudi Arabia and the United Arab Emirates - seem to be unlikely candidates for a large-scale expansion of renewable energy. These six countries are major fossil fuel exporters, supplying $24 \%$ of the world's oil and $11 \%$ of its gas. They hold $30 \%$ of the global proven oil and $23 \%$ of the proven gas reserves. In all GCC countries, the proven gas and oil reserves have increased or remained constant over the last 20 years, and reserve/production (R/P) quotas exceed 30 years in most GCC countries. The big producers state especially high R/P quotas: Qatar and Saudi Arabia, for example, have gas R/P quotas of 155 and 80 years, respectively, whereas the Saudi and Qatari oil R/P quotas are 63 and 74 years, respectively [1]. Hence, introducing renewable energy does not appear to be an immediate necessity; indeed, the very low number of projects developed in the Gulf does not indicate an urgent need to change the status quo.

At the same time, the deserts of the Arab peninsula hold vast resources for renewable energy, in particular solar energy. This potential would easily suffice to satisfy any regional future energy and electricity demand with solar power: the German Aerospace Centre (DLR), for example, identifies the potential for concentrating solar power alone - thus excluding PV, wind power and all other renewable energy sources - to be $150,000 \mathrm{TWh} /$ year [2]. This is roughly the global primary energy consumption in 2012, whereas the GCC countries themselves had an electricity generation of $470 \mathrm{TWh} / \mathrm{year}$ and a primary energy demand of $4400 \mathrm{TWh} / \mathrm{year}[3,4]$. Consequently, some suggest that a large-scale expansion of renewable electricity in the Gulf countries may be beneficial, to supply both the Middle East itself and, in the longer term, to export renewable electricity to Europe [5-11].

This combination of strong reliance on fossil fuel production, consumption and exports leading to availability of large amounts of capital on the one hand and massive renewable resources on the other make the GCC states an interesting renewable energy policy case. In this paper, we investigate whether a business case for renewables in these countries is present, what obstacles stand in the way of renewables, and what it would take for a large-scale renewable expansion to happen in the future.

\section{Method and Materials}

To find answers to these questions, we carried out a meta-analysis of data contained in the peer-reviewed literature about renewables in the GCC countries and surveyed the view of stakeholders active in the renewable energy sector in the GCC region through a questionnaire and conference discussions. The questionnaire was distributed to the participants of the International Energy Agency (IEA) and International Renewable Energy Agency (IRENA) event Renewable Energy Investment in the GCC at the World Future Energy Summit in Abu Dhabi in January 2014. Participants at this high-profile event were mainly from the investment and manufacturing industry communities as well as from government agencies. We chose this event for the distribution of the questionnaire, as we were interested in the views of stakeholders active either as investors or project developers, or from the administrative side in government, as opposed to, say, the opinion of the general public. In addition to the questionnaire, the discussions and findings at the IEA/IRENA conference have also served as input to this article; we include the insights generated during these discussions in the results from the questionnaire in Section 4. 
We structured the literature analysis around drivers for and barriers to a renewables expansion in the GCC countries (see Section 3). In order to focus the questionnaire, we defined a logical chain of questions to find out whether there is a need and a case for renewables in the GCC region, what the barriers and risks preventing an expansion today are, and how these can be overcome. We structured the questionnaire around five main questions, each of which had up to 11 sub-questions (the full questionnaire is found in the Supplementary Material):

1) What is the overall case for renewables in the GCC region?

2) What are the most challenging barriers to scale up RE investments in the GCC?

3) Which of the following risks do you think exist in the GCC for RE investments?

4) Ignoring issues of their current political feasibility, which of the following policies and incentives do you think could make a major impact to stimulate investment in renewable energy in the GCC region?

5) Many countries have developed renewable energy targets or road maps. Which of the following statements do you agree with?

We asked the sub-questions in the form of a statement (e.g., "There is insufficient engineering capacity in the region to engage in project development" or "Future market and support policies are likely to change in an unfavorable direction"), to which the respondents gave answers on a five-point Likert scale. This was complemented by questions about the respondent's experience of renewables in the GCC countries, whether the respondent's company planned to expand its renewable energy activities in the GCC, and what type of organization the respondent works for.

\section{Results: Literature-Based Analysis}

Despite the large potential for renewables, very few renewables have been built in the GCC countries. The IEA reports zero renewable electricity and energy generation in the GCC for 2011 [4]. Ferroukhi et al. [12] list $65 \mathrm{MW}$ of renewable electricity capacity, which is approximately the amount that were installed in Germany each hour, on average, over the last five years [13]. There are some 1240 MW under construction (including the Shams 1 CSP station, the $100 \mathrm{MW}$ of which are operational since 2013 [14]), and another 3300 MW planned, announced or in ongoing tendering processes. At the core of the more optimistic views on GCC renewables are the various flagship projects that have emerged in recent years, such as Masdar City in UAE or King Abdullah City for Atomic and Renewable Energy (K A CARE) in Saudi Arabia. A few high-profile power stations are in planning, like two further CSP units at Shams in Abu Dhabi, or the announced $1 \mathrm{GW}$ Mohammed bin Rashid al-Maktoum solar PV park in Dubai, of which the first 13 MW opened in 2013 - the full $1000 \mathrm{MW}$ are to be achieved in $2030[12,15,16]$.

\subsection{Drivers for Renewable Energy in the Gulf Cooperation Council Countries}

Despite the topical focus on fossil fuels in energy and energy policy research for the Arab Gulf countries, there are also some authors who have focused their research efforts to renewables in these countries. The bulk of these studies assess the size and quality of the solar energy resource (see the overview of 56 2005-2013 GCC studies summarized in [17]), and arrive at results similar to that cited 
in the introduction: the solar energy resource in the GCC is enormous. This resource is not only larger than elsewhere because of the size of available desert land, it is also better: for example, the GCC solar radiation is up to three times higher than in central Europe $[2,7,17,18]$. In addition, as the electricity demand is driven by the use of air-conditions and peaks in summer, both solar PV and concentrated solar power fit the prevailing seasonal demand fluctuations.

A number of authors move from the technical realm towards policy, and this body of research has identified four main drivers for a renewable energy expansion in the GCC (e.g., [7,10,12,16-26]):

1) Renewables could help to satisfy the rapidly increasing energy and electricity demand in the GCC, which is driven by economic and population growth, and by an increasing need for water desalination;

2) Renewables would diversify the domestic energy mix and free fossil fuel resources for more profitable export;

3) A renewable energy manufacturing industry, especially for currently immature but highly promising technologies (e.g., CSP), is an option to diversify the GCC economies, attain technological leadership and create new high-quality jobs outside the fossil fuel sector, or to offer a new energy export commodity;

4) Expanding renewables would reduce the climate footprint of the GCC countries.

\subsubsection{Increasing Demand}

The energy and electricity demand has increased by 5\%-10\% per year over the last decade, driven by population growth, increasing economic activity and heavily subsidized energy prices; the electricity and energy demand has almost doubled in the last decade [3]. Today, the GCC energy demand is among the highest in the world; per-capita primary energy consumption is about 2.5 times that in the EU. Seawater desalination is expected to add to this demand increase, as all GCC countries are experiencing strong and increasing water stress [27]. Hence, the GCC countries need to expand their energy and electricity supply quickly, which they have done in the past by diverting oil and gas from the export sector to the domestic energy systems and by building oil- and gas-fired power stations, which today supply $40 \%$ and $60 \%$ of the GCC electricity $[3,4]$. The abundance of domestic fossil fuels and the prevalence of energy consumption subsidies have not built up the pressure for economic or resource efficiency that can be observed in, for example, Europe or Japan; hence, the energy markets are at a very early stage of liberalization and renewables are, to date, almost non-existent [28].

\subsubsection{Subsidies and Reduced Fossil Fuel Export Opportunities}

All GCC countries subsidize energy consumption. These subsidies are a large and increasing problem for the GCC states, both as the subsidized prices allow for an ever increasing demand and put serious strain on public funds (especially when world market prices for fossil fuels decrease), and as the increasing domestic demand removes production capacities from the much more lucrative foreign markets. In total, the six GCC states spend more than US\$100 billion per year on energy subsidies, half of which are on petroleum products [29]. For example, the Saudi and Kuwaiti pump price for 
gasoline is below $0.25 \mathrm{US} \$ / \mathrm{L}$ (which is about $40 \mathrm{US} \$ / \mathrm{bbl}$ gasoline-well below even the unrefined crude oil price), to be compared with the average EU27 gasoline price of $1.75 \mathrm{US} \$ / \mathrm{L}$ (using a EUR-USD conversion rate of 1.15 USD per EUR). The Kuwaiti household electricity price is around $0.7 \mathrm{US} \$ \mathrm{c} / \mathrm{kWh}$, although the average LCOE is around $12 \mathrm{US} \$ \mathrm{c} / \mathrm{kWh}$, see Table $1[12,26,30]$. For all energy carriers, the Saudi Arabian energy consumption subsidies cost 11\% of its GDP in 2011 [10]; in the other GCC countries, this was 3\%-6\% in 2010 [12,31,32].

This is typical rentier state behavior: the state uses the resource abundance to "buy" peace and stability through large-scale distributive policies (typically combined with repression). Energy subsidies are thus a part of the stability-enhancing "social contract" between energy rentier state governments, such as those in the GCC countries, and their populations [33] (see Section 3.2.1 for a more detailed discussion).

Table 1. Average electricity prices in the Gulf Cooperation Council (GCC) countries 2011, US\$/kWh. Sources: [26,30].

\begin{tabular}{cccc}
\hline Country & Domestic residential & Foreign residential & Industrial \\
\hline Bahrain & 0.8 & 0.8 & 4.2 \\
Saudi Arabia & 1.3 & 1.3 & 3.2 \\
Kuwait & 0.7 & 0.7 & 0.4 \\
Oman & 2.5 & 2.5 & 3 \\
Qatar & 0 & 2.5 & 1.9 \\
Abu Dhabi & 1.3 & 4 & 4 \\
Dubai & 2 & 6 & 6 \\
\hline
\end{tabular}

In $2012,21 \%$ of the oil and $57 \%$ of the gas produced in the GCC was consumed domestically. The value of this oil on the global market, given an average price of 109 US\$/bbl, was US\$175 billion, whereas the gas was worth US\$70 billion on the British and US\$125 billion on the Japanese LNG markets [3] - about $20 \%$ of the GCC GDP [34]. Hence, a wide array of measures to reduce domestic fossil fuel demand, such as supply-side or end-use efficiency or an increase of renewable power, are in principle financeable - at least to the largest part - directly with these fossil-fuel export gains [25].

Renewables are a main supply-side alternative to address both the consumption subsidy and demand increase problem at a large scale. Whereas the bulk of the literature on renewables in the GCC sees the current costs of renewables as a serious barrier to expansion, others remark that PV, CSP and wind are cheaper than oil-fuelled electricity — which supplies a third of GCC electricity today — and wind power is competitive with gas-fired mid- and baseload power plants. Including the opportunity cost of burning fossil fuel domestically instead of exporting them would make both solar and wind power profitable in the Gulf already today [10,25,35].

All GCC countries, except Oman [36], have defined renewable electricity targets, albeit at an internationally modest level, see Table 2 . Nevertheless, given the size of some markets, especially the Saudi Arabian market, and the massive demand growth, even comparatively slow expansion rates mean a large expansion of renewables: the Saudi CSP target alone represents a 12-fold expansion of global CSP capacity compared to 2012 [37]. 
Table 2. Renewable electricity targets for the GCC countries. Source: [38].

\begin{tabular}{ccc}
\hline Country & Target (\% of Generation) & Year \\
\hline Bahrain & 5 & 2030 \\
Kuwait & 5 & 2020 \\
& 10 & 2030 \\
\hline Oman & -- & -- \\
\hline \multirow{2}{*}{ Qatar } & 6 & 2020 \\
& 10 & 2030 \\
\hline Saudi Arabia & 30 & 2032 \\
\hline United Arab Emirates & & \\
\hline Abu Dhabi & 7 & 2020 \\
\hline \multirow{2}{*}{ Dubai } & 1\% of installed capacity & 2020 \\
& $5 \%$ of installed capacity & 2030 \\
\hline
\end{tabular}

Note: There is uncertainty about the targets of some GCC countries, which also casts doubt on the actual political commitment to reaching them. We cite the numbers of the League of Arab States and IRENA, which we deem the most reliable source, whereas others, for example Ferroukhi et al. [15], give somewhat other figures.

\subsubsection{Economic Diversification and Job Creation}

Numerous authors point to the job creation potential and the opportunity to diversify the GCC economies by building up a renewable energy industry [10,17,20,25,26]. Such hopes are typically based on parallels to Europe, and especially Germany, where in 2012, some 380,000 people worked in the German renewable energy sector $[39,40]$. For the GCC and other countries in the desert belt, the argument goes, there may be a niche for a sizeable solar power industry, especially technologies adapted to the desert climate, with a potential for the formation of a new industry branch and the large-scale creation of highly qualified jobs $[17,25,41]$. A recent IRENA study quantified the gross renewables industry job potential in the GCC to 0.6 million by 2020 and 1.8 million by 2030, if solar power is expanded and policy emphasizes the local supply chains [26]; estimates for an expansion of the CSP sector in North Africa to support exports of $700 \mathrm{TWh} /$ year to Europe indicate a potential of 100,000-300,000 induced direct and indirect industrial jobs, depending on the local manufacturing share [42].

Today, there is practically no renewable energy component manufacturing industry in the GCC, largely because of the very small domestic market for renewables. Some GCC investors, like Masdar Clean Energy or ACWA, are however active in the global renewables market. A few down-stream supply chain factories are emerging, in particular in the energy-intensive-much due to the low and subsidized energy prices-PV-grade silicon production [12,26,43].

Although official unemployment is relatively low in the Gulf, the youth unemployment is in part rampant, ranging from a very low 1.7\% in Qatar to over 25\% in Bahrain and Saudi Arabia, and another 2.8 million young persons enter the GCC job market each year [34,44,45]. In Saudi Arabia, for example, some $35 \%$ of the national population has a job, compared to $60 \%$ in the member countries of the Organization for Economic Co-operation and Development (OECD), and non-nationals fill the majority of positions in the private sector [46]. Based on past experiences, therefore, it seems possible that qualified jobs, should they arise in a new renewable energy industry sector, will go to imported laborers and not necessarily to the local population. Changing this is not easy: making well-paid, 
but often low-productive, jobs for a part of the domestic population is a characteristic of rentier states (see Section 3.2.1) and is a part of the social contract for stability between government and population; abolishing such jobs and letting productivity and market forces shape the job market and salaries is thus a potential threat against the national government. Hence, a renewables expansion can indeed be one step towards economic diversification, especially if a domestic manufacturing sector emerges, but it will neither be easy to achieve in the political setting of the GCC nor will it be a silver bullet for GCC employment problems.

\subsubsection{Carbon Footprint}

Finally, many authors present data suggesting that the carbon footprint of the GCC countries is among the highest in the world, not only because of its fossil fuel production but also due to the high domestic energy demand. In addition, the desert countries of the GCC are highly vulnerable to climate change. All GCC countries are signatories to the UNFCCC and the Kyoto protocol, which to these authors is a clear sign of the GCC countries' ongoing turn towards sustainability $[12,17,19,20]$. In reality, however, the GCC countries - some more than others-have slowed down the international climate negotiations [16,47], while not pursuing any type of serious climate protection domestically. No country except Dubai-which aims to reduce their emissions by $1.5 \mathrm{Mt} \mathrm{CO}_{2}$ per year-has a climate target [26].

\subsection{Barriers to Expansion of Renewables in the Gulf Cooperation Council Countries}

There is a strong mismatch between the in-principle strong reasons for GCC countries to pursue a renewable energy pathway and the actual, observable action. In the literature, a number of authors have touched upon barriers and risks to renewable energy in the Gulf, but they are less well researched than the drivers.

The drivers are all of a long-term nature, based on strategic considerations, whereas the barriers are more direct and short-term. Five principal barriers identified have been in literature (esp. [12,16,17,22,26,29,30,48,49]), of which the first three points are related to rentierism and the resource-dependence of the political and economic system of the Gulf states:

(a) Absence of a market for renewables, due to fossil fuel and energy-use subsidies, as well as market entry difficulties due to the non-liberalized market structure;

(b) Absence of support policies for renewables, including both grid access regulations and financial support schemes;

(c) Resistance from incumbent actors in the fossil fuel industry and policies to implement such schemes;

(d) Insufficient know-how and experience of renewables (e.g., lack of engineers);

(e) Intermittent wind and PV generation is not easily integrated into the existing electricity system. 


\subsubsection{Energy Subsidies and Inefficient Bureaucracy: Rentierism}

The lack of supporting policies combined with the very low, subsidized electricity prices (see Table 1) form a sort of "super-barrier": no renewables can compete with such prices $[19,26]$. Until recently, none of the GCC countries had a renewables support scheme in place $[12,17]$ and the overall quality of energy legislation in general is "actually very poor" [22]. In Abu Dhabi, the Shams 1 CSP station is financed with a feed-in tariff [26], whereas Kuwait and Saudi Arabia have tendering schemes in progress [43]. These schemes have not triggered any investments, as the tendering processes are, at the time of writing, still on-going. In principle, most Gulf monarchies have the financial means to expand renewables in a state-driven approach [50], but so far they have not opted for renewables, to a large extent because of the interests of the powerful energy industry and how the political system of rentier states such as the Gulf countries work.

Although the energy subsidies are a drain on public funds and although they lead to a wasteful energy usage pattern, removing them is not an easy task, nor is it clear that doing so is an attractive option for the governments - especially not for the ruling persons themselves. Cheap energy is a means of distributing the fossil fuel wealth within countries [16] and is often seen as "a right of citizenship" [12,30]. The "paradox of plenty" describes how resource-rich countries suffer from economic stagnation (outside the extracting sector), corruption and authoritarianism [33,51,52]. Some export-dependent countries experience a direct resource curse, where unrest or even civil war over control of the resource is triggered and financed by exports of the good, especially lootable goods such as oil, diamonds or narcotics [51]. This is particularly the case if countries are highly dependent on exports but export revenue per capita is low and institutions weak, such as in Nigeria or Algeria [53,54].

Other resource-rich countries are rather rentier states, which suffer from the problems mentioned above, but are stable and do generally not experience civil war. Such countries are rich in export revenue per capita and manage to buy peace and internal stability through "a combination of large-scale distribution, high spending on the security apparatus, protection by outsiders and relatively more favorable state institutions" [33].

The GCC countries are rentier states, rather than resource curse states, as indicated by the long period of sustained peace on the Arab peninsula - and the fact that the Arab Spring has left the GCC countries and ruling elites largely unscathed. Indeed, a primary GCC country policy response to the overthrow of autocrats in other Arab countries was to increase social spending and postpone or cancel subsidy reform [30]. Rentier states are thus stable, but are strongly focused on one economic sector. The economic redistribution of wealth happens through energy subsidies (see below) and through privileged-well paid but unproductive-government employment (see also Section 3.1.3). Such employment is another way of redistributing resource wealth, and tying opponents into the rentier system through patronage employment allows rulers to incentivize cooperation, and not conflict, among rival families [53]. Consequentially, rentier states typically have bloated and inefficient bureaucracies, so that red tape and corruption hinder investments and economic development outside the extracting sector, especially for foreign investors [54].

Energy subsides are the other main instrument to redistribute wealth and buy stability, but, simultaneously, it poses a great drain on government funds and removes incentives for efficient energy consumption. Hence, abolishing energy subsidies would be beneficial for the economy, for the state 
budget, for controlling the energy demand increase, and it would make renewables more competitive. Yet, the GCC countries maintain their subsidy systems. A part of this explanation lies in the political system of rentier states: stepping off the fossil fuel path, especially if done by removing fossil fuel sector privileges, would also be a potential threat to political and social stability and the continuity of rule for the ruling families, both in the extracting industries and in government. On the other hand, such reforms could be important to maintain exports and export revenues - the lifeline of the regimein the long run: abolishing energy subsidies thus holds a conflict between the short-term risk to and the long-term survival of the regime [30].

Removing energy subsidies would have direct effects by increasing the energy expenditures for citizens and companies. For the poor population, this could mean that they no can longer afford the energy they need, which is a social problem. This would be exacerbated by indirect effects, such as increasing prices when the higher energy prices trickle through the entire economy [31]. Perhaps more problematic for the ruling elite, higher-income and more powerful citizens are more affected by subsidy reforms, as they tend to use more energy than poorer people.

The difficulty of abandoning energy subsidies is visible in Iran, where the government began abolishing energy subsidies and replaced them with direct compensation payments to citizens and companies in 2010. This reform resulted in the over-night increase of consumer energy prices of up to $2000 \%$, and inflation rapidly increased to over $20 \%$, the lion's share of which was directly caused by the subsidy reform $[55,56]$. This greatly contributed to the crash of the Iranian economy, which, in turn, likely contributed to the political instability in the years after the reform. In the Gulf monarchy context, with the Iranian reform experience and the events of the Arab Spring in mind, the political elite can be expected to be aware of both the potential economic benefits and the political dangers of abandoning the re-distributive energy subsidy schemes [31].

The interests of policy and the power of the extracting industry can be observed in the lack of openness in the energy systems across the Gulf countries, including the non-export electricity sectors. None of the markets are liberalized, but liberalization processes have started across the region. Generally, private investors are allowed to engage in electricity projects - in principle, also renewables — only together with national energy companies and authorities. This reduces risks like off-take risks but increases the risks of planning: once the deal is made with the national company/authority, there is hardly any off-take risk, but the deal can be exposed to a great deal of uncertainty, including arbitrariness in decisions and corruption [12,17,25,26,28].

In addition, a number of energy-intensive companies have been attracted to the region due to the low energy costs - not least the planned PV-grade silicon factories - and removing subsidies could pose a problem to this sector: at least part of the ongoing economic diversification relies on continued energy subsidies.

\subsubsection{Insufficient Experience and Knowledge}

Some authors emphasize that there may not be sufficient engineers and know-how available for an immediate expansion of renewables. If this is true, engineers would need to be imported, adding to the employment problems described in Section 3.1.3. However, some new education programs focused on renewables are emerging, especially within the "sustainability cities", like Masdar and KA CARE, 
and some universities - such as in Kuwait and Qatar-are educating solar energy engineers [12,26]. Similarly, some authors suggest that investors and policy are simply not aware of the opportunities of renewables, such as their good cost performance compared to petroleum-fired power stations or possibilities to fuel desalination, and therefore do not consider them a useful option for the future $[12,36,38,49]$.

\subsubsection{Integration of Intermittent Generation}

The integration of volatile electricity generation into existing power systems is sometimes suggested as a problem in the GCC, just as elsewhere in the world [22,43]. Although the fit between solar power generation and electricity demand is good on a seasonal scale, the Gulf countries have two demand-peaks per day: one during the afternoon, when it is hottest, and one at night after sundown, when the humidity rises in the coastal cities. Solar PV can only satisfy the mid-day peak, whereas CSP with thermal storage could meet both [17,25,35,57-59]. However, given the flexible nature and large share of gas power plants GCC power grids, the existing generation fleet is well prepared to balance intermittent renewables [25,26].

\section{Questionnaire Results}

We received a total of 107 questionnaire responses, of which not all were complete. The number of valid replies for each question is indicated in the graphs below. Of the respondents, about $20 \%$ were project developers, whereas some 25\% were from a government agency, see Figure 1.

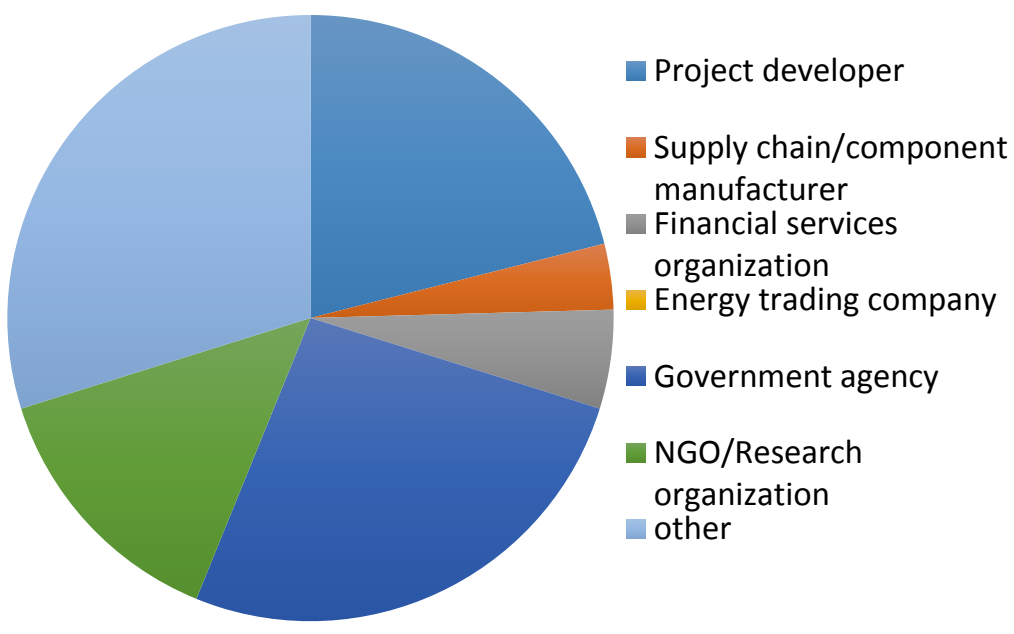

Figure 1. Distribution of respondents to organization type.

Of the respondents, 53\% had experience with investments in renewable energy in the GCC countries, and $88 \%$ expected to increase their activities in this sector in the near term. Over $60 \%$ of the respondents had seven or more years experience with renewable energy, and $40 \%$ had been in this business for more than 10 years. 


\subsection{The Need}

The first question concerned the general case and the need for renewables in the GCC region. The respondents were very confident that there is a need and a potential business case for renewables in the GCC countries: almost $90 \%$ of the respondents disagreed that there is no such case. Hence, from the viewpoint of the respondents, a lack of need for renewables is not the reason for the currently low expansion rates. The more experience the respondents had, the more positive they were towards the general outlook for renewables in the GCC states. Equally, those who planned to expand their activities in the coming years were more optimistic about the general outlook for renewables. At the same time, a lack of a pressing imperative for a short-term expansion of renewables was highlighted as an important barrier at the conference: fossil fuels are still abundant and electricity prices are low, so that GCC countries - other than many other countries elsewhere in the world - are not forced to urgently start looking at renewables. Possibly, this mismatch is caused by a future/present conflict: the need for renewables is mainly based on expectations of the future. The respondents found that fossil fuel depletion requires GCC states to begin diversifying their energy mix, and the volatility of fossil fuel prices increase the attractiveness of investments in renewables. The respondents who feared depletion were more likely to worry about price volatility, indicating that one impact may be seen as leading to the other. This finding was confirmed in the conference discussions. The respondents coherently expected that investors and companies that build experience today would profit in the future (see Figure 2).

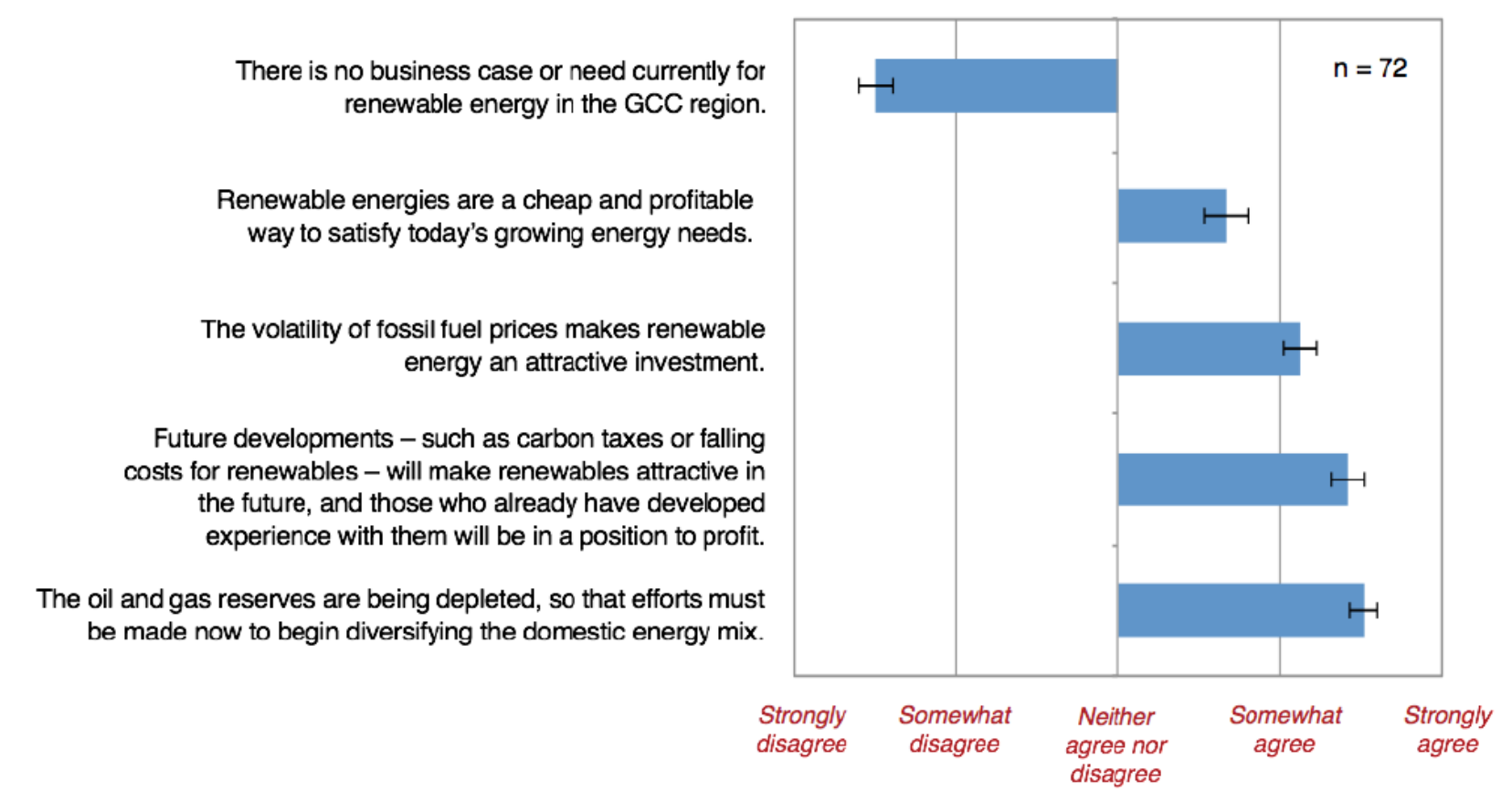

Figure 2. Results of question 1 - the overall case and need for renewables in the GCC countries. The bars show the mean value and the error bars show a confidence interval of one standard error. 


\subsection{The Barriers}

The second question focused on barriers to investments in renewables in the GCC region. Respondents were very confident that the climatic and geographical conditions for renewables in the GCC are good; respondents who planned to increase their activities in the future were particularly optimistic. This confirms the dominant view in the literature: the very large potential for renewables in the GCC countries is the foundation for considering renewables in the first place, and the specific natural risks of renewable energy facilities in deserts are very likely to be manageable (e.g., [60]).

The main barriers to investment are political: the absence of a support framework and red tape are, by far, the most important barriers. At the conference in Abu Dhabi, the combination of fossil fuel subsidies, which artificially lower prices, and an absent renewable energy support framework, were found to be the most important barrier to investments in renewables. Interestingly, despite the lack of a support scheme and the red tape risks, 2/3 of the respondents believed that it is possible to raise finance for projects today (see Figure 3). This finding was confirmed at the conference. This may be a contradiction but may also reflect the high visibility of the various flagship projects across the region: evidently, it is possible to raise capital and build renewable power stations, at least in specific cases.

Other barriers, such as too many risks and a lack of engineers and know-how are not seen as important obstacles; respondents with more experience are particularly clear in discarding such suggestions. Further, our findings reject those, for example [22,38], concerning grid integration: our respondents did not see weaknesses in the electricity transmission system as a serious barrier. On the contrary: at the conference, a good match between the solar power supply curve and the cooling-dominated demand was highlighted as a key advantage for the expansion and development of solar power in the GCC compared to the rest of the world.

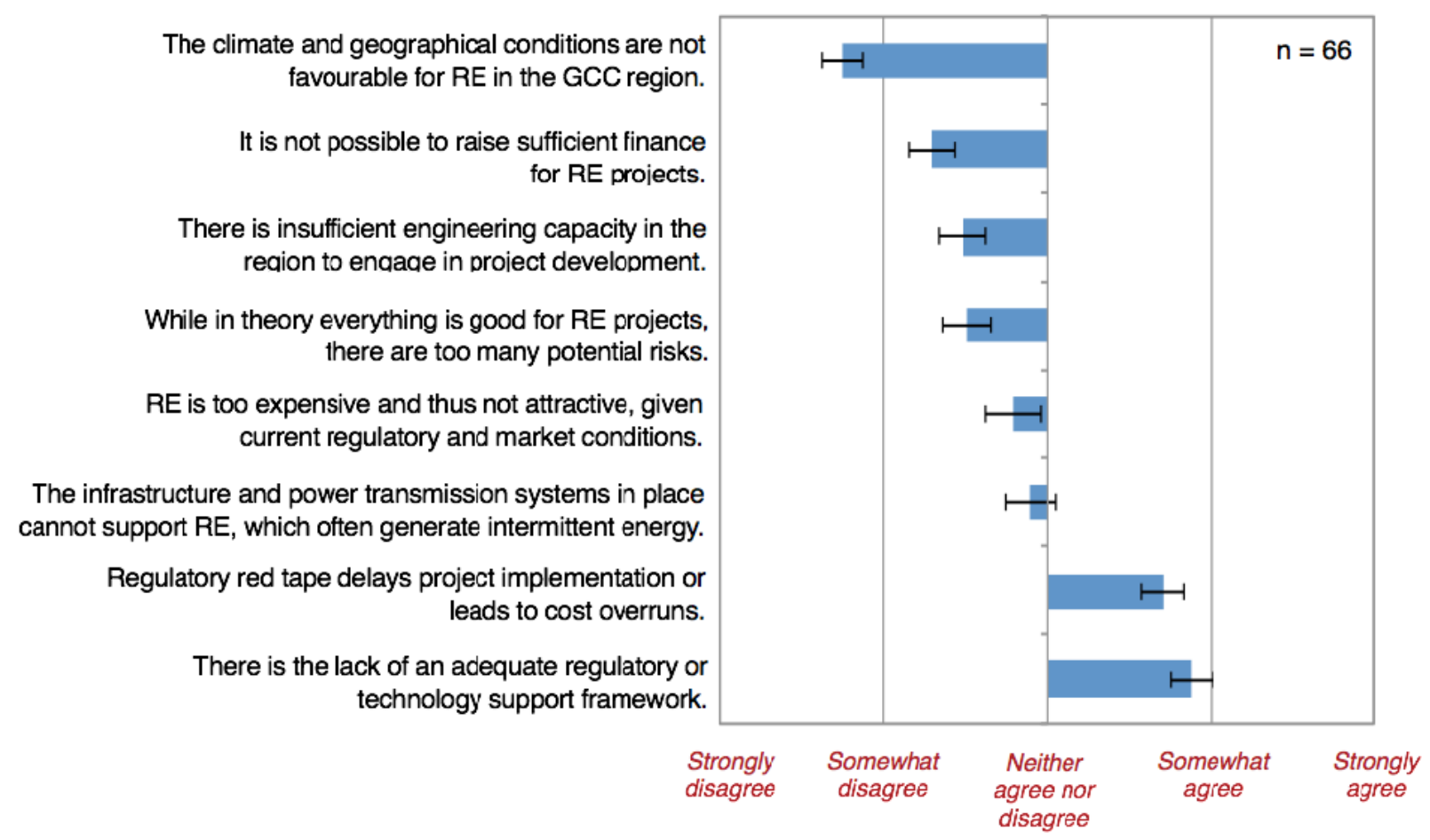

Figure 3. Results of question 2-the most challenging barriers to scale up renewables in the GCC countries. 


\subsection{The Risks}

The third question investigated the risks to investment in renewables in the GCC countries. Respondents did not clearly agree with any of the answers provided, but they did not see any serious public opinion risks or serious risks of political unrest or terrorism (see Figure 4), thus confirming results from the energy security literature [61,62]. The respondents did generally not support the suggestion that policies are likely to change in an unfavorable direction in the future; the longer their experience in renewable energy investments in the GCC, the less the respondents feared unfavorable or retroactive policy changes. However, given the absence of a support scheme and other supporting renewable policies, it is surprising that there is weak disagreement concerning off-take risks, especially among experienced respondents.

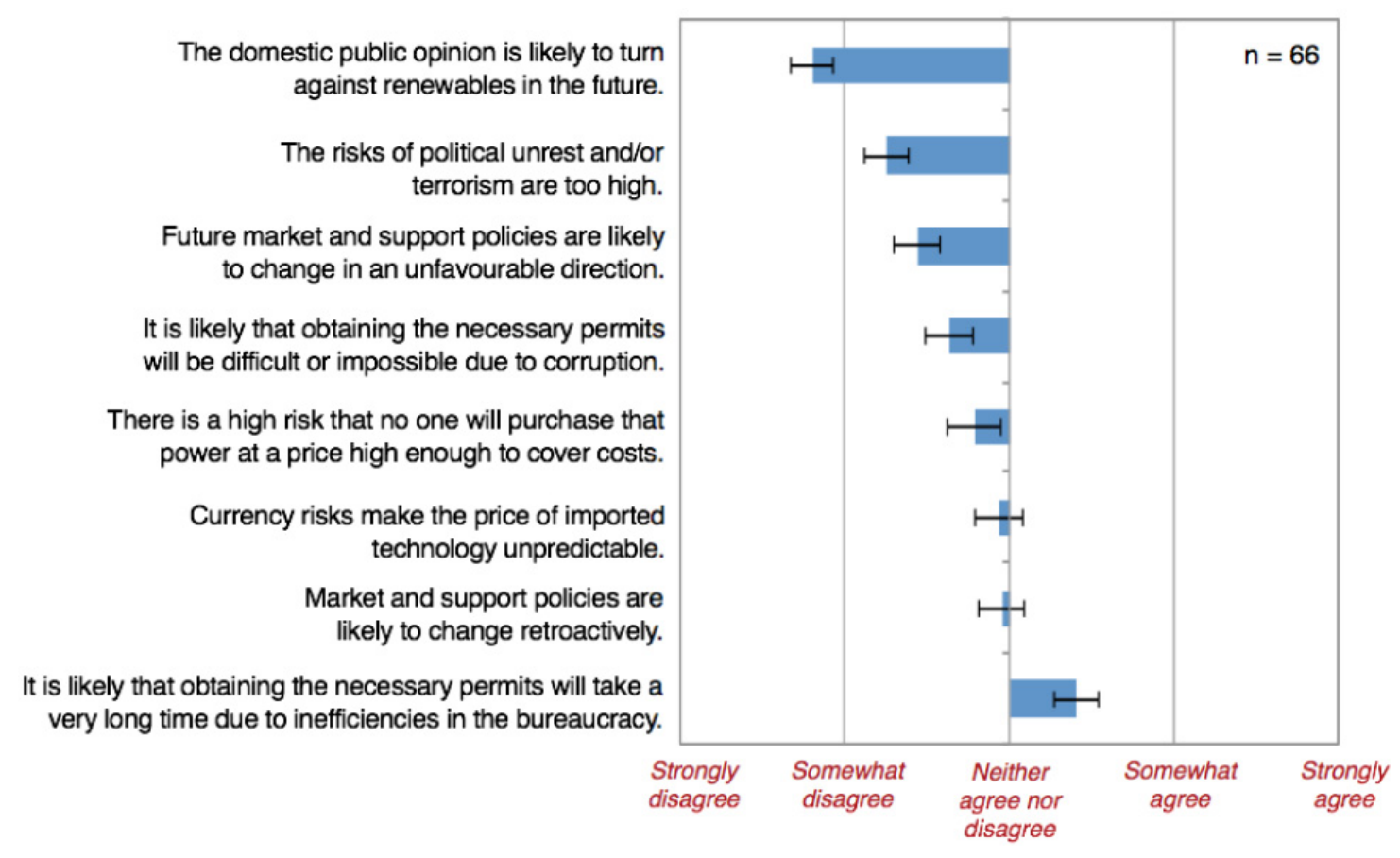

Figure 4. Results of question 3-risks to investments in renewables in the GCC countries.

The only risk we can consistently identify as important is the risk of bureaucratic delay: $63 \%$ of respondents agreed or strongly agreed that this is an important risk, especially if they also saw bureaucratic inefficiency as an important barrier in question 2. This supplements the findings of $[63,64]$, who assessed the situation in North Africa: red tape is both a serious risk and an important barrier to investment. However, our respondents disagreed — weakly or strongly — to all other risks; respondents with longer experience valued these risks as even less important. These rejected risks include political unrest and policy instability, which were identified in $[63,64]$ both as important risks and barriers to investments in renewables in North Africa. These two risks are not mentioned as important in the dedicated GCC renewable energy policy literature (see Section 3) and they were not highlighted at the conference, which is in line with the "rentier peace" hypothesis confirmed in literature [33]. Possibly, however, issues like corruption, unpredictable policies and political instability are seen by our respondents as a problem only in some GCC countries - such replies would have been masked by our grouping together of all six countries as GCC. Indeed, the 2014 Edelman trust barometer shows that 
general trust in government is very high - the highest of all assessed countries - in the UAE, especially concerning its energy policy [65]. As many conference participants were from the UAE, this may have contributed to "hiding" lower trust of participants from other countries.

As a final remark, our low-risk but high-barrier results may appear inconsistent but are not necessarily so. As respondents viewed current policies as generally unfavorable (high barrier), they were unlikely to turn even more unfavorable in the future (low risk). For example, if there are no beneficial support schemes in place, they cannot — of course — be changed retroactively.

\subsection{The Policy Solutions}

The fourth question asked about possible policy solutions to overcome the barriers and manage the risks to investments in renewables in the GCC countries. The respondents agreed to all suggested policy instruments, except the proposition that only public investments can trigger an expansion of renewables (see Figure 5). We interpret this as a perceived lack of all functions these policies would provide: the lack of a support scheme is reflected in the desire to implement one-almost regardless of the type, although the feed-in tariff is the most preferred instrument. Similarly, the inefficient bureaucracy needs to be improved to enable the implementation of in principle attractive projects, and the fossil fuel and electricity subsidies must be removed by liberalizing the domestic markets and introducing a fair price mechanism.

The only policy measure that was significantly more supported than others were a feed-in tariff system: respondents, as well as many participants at the conference, believed that this policy measure would make a larger positive difference towards expanding renewables than any of the other instruments. The more experience the respondents had, the more likely were they to see this as a key policy solution. Importantly, respondents with more experience were more likely to have given strong support for bureaucracy improvements, market liberalization and feed-in tariffs. A reasonable assumption is that these respondents knew the investment environment better than the others; we thus interpret this as a strong indication that these three policy measures are the most important ones to enable investments in renewable energies in the GCC countries.

Further, the high level of agreement with a feed-in tariff and the comparatively low agreement with renewable electricity quotas, carbon taxes and emission trading is consistent with the results of numerous European studies, showing that quotas and emissions trading are neither effective nor efficient measures to trigger an expansion of renewables (e.g., [5,66-68]). Finally, investors who had a large share of their activities in the renewables sector of the GCC countries found increased information about investment opportunities a more important instrument: this was expected, as those who are already active in the sector know about the opportunities and may thus believe that others simply do not know about them.

The results of the policy solution question, however, also hold an inconsistency: there was strong agreement that most of the suggested policy instruments could make a positive difference and overcome barriers and risks, but at the same time there was weak agreement that no policy measure could have a major impact on the investment situation right now. This is an inconsistency, and we suspect that many respondents may have misunderstood the "no policy makes a change" statement, 
as the statements in the format of "this measure would make a major impact" are more expected in a questionnaire and are harder to misunderstand.

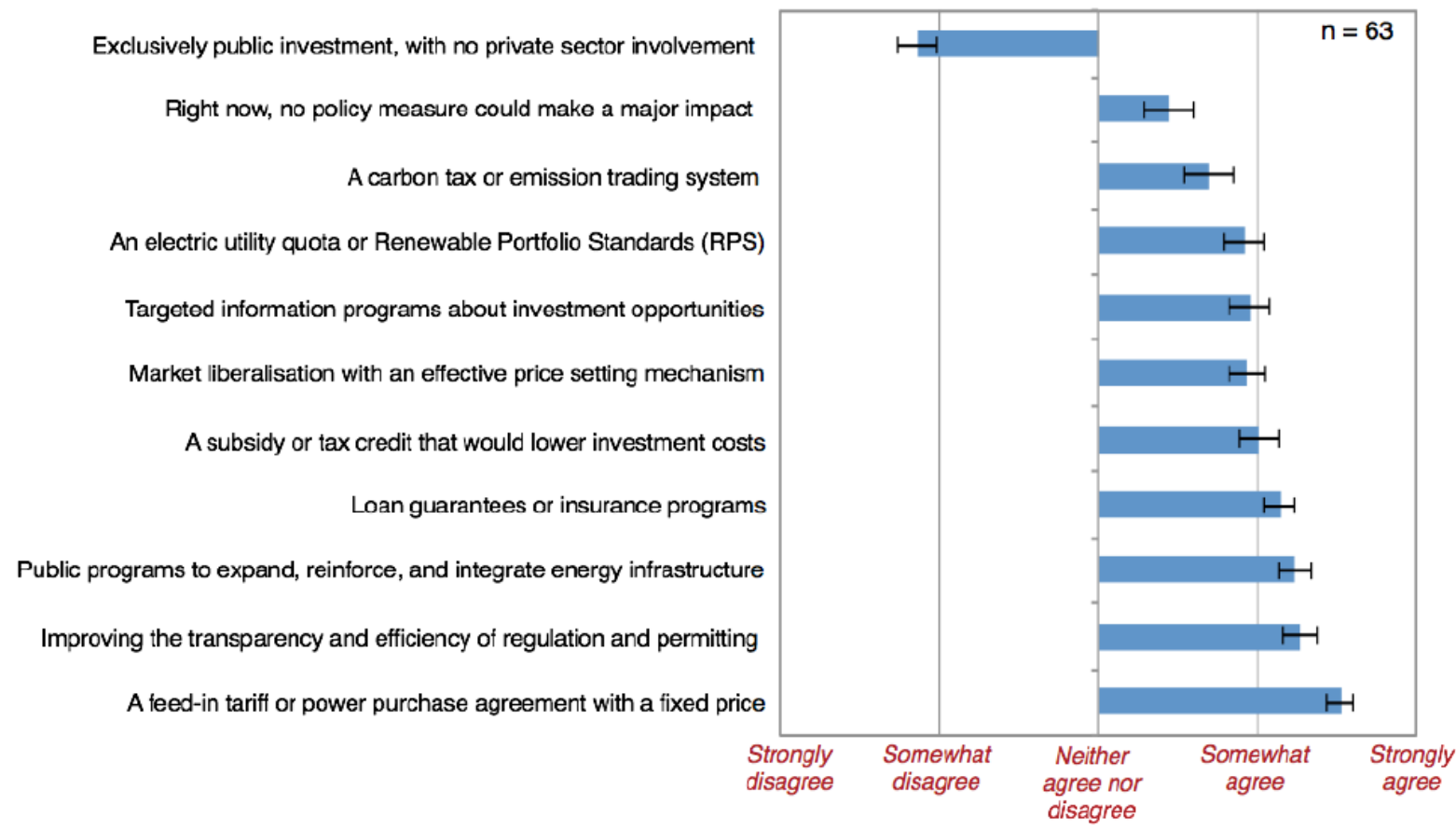

Figure 5. Results of question 4-policy solutions to overcome investment barriers and risks in the GCC countries.

\subsection{The Roadmaps and Targets}

The fifth question asked about the importance of roadmaps and renewable energy targets. The findings based on the questionnaire as well as the conference discussions are very clear: targets and roadmaps are necessary first steps towards a coherent policy framework to support the expansion of renewables, but they are not sufficient on their own (see Figure 6). Interestingly, $41 \%$ of respondents viewed targets as merely symbolic acts of policy.

Targets and roadmaps are already sufficient on their own to trigger investments in renewable energies.

Targets and roadmaps do not promote investment, because they are merely symbolic steps to promote renewable energy whereas actual policies do not change.

Targets and roadmaps are a necessary first step towards a country's developing a coherent national policy framework to support renewable energy.

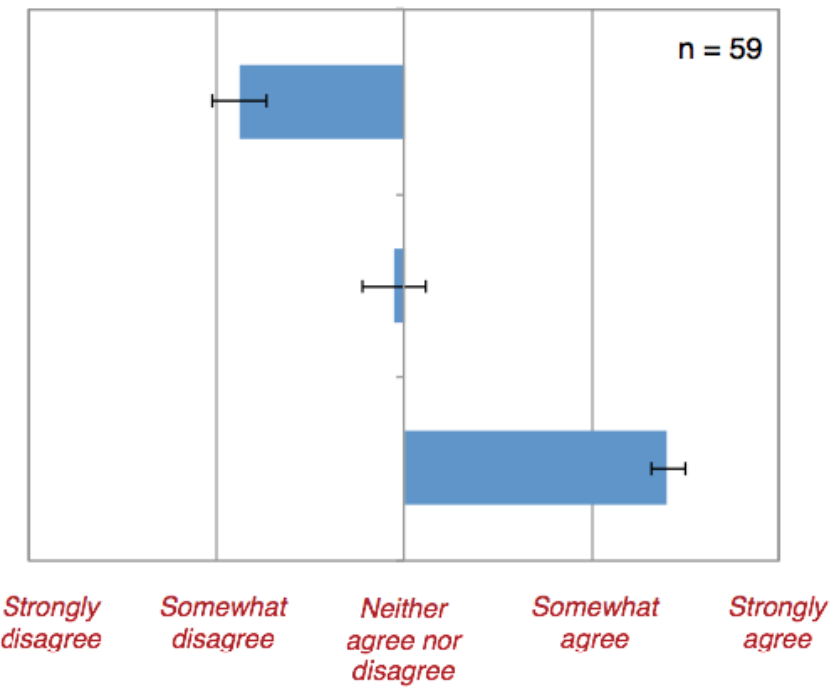

Figure 6. Results of question 5-targets and roadmaps. 


\section{Discussion}

Our survey and literature analysis results indicate that there is, in principle, a need and hence a potential business case for renewables in the GCC countries, at least in the future. At the conference in Abu Dhabi, the potential to become a technology leader for solar energy technologies was highlighted as a major imperative for GCC countries to start expanding renewables quickly, as a part of a strategy for economic growth and diversification. Different landmark projects, like Masdar City or the Shams CSP station, show that such thoughts have reached both policy and energy industry in the GCC. At the same time, conference participants emphasized that the pressure on GCC states to increase renewables now is low, as fossil energy is still abundant, and the economic pressure to change is low. The very slow expansion of renewables in the Gulf shows that this reasoning is still strong in mainstream policy. Hence, there is tension between these two rationales, and it remains to be seen which one prevails.

The present renewables business case is prevented by a number of barriers, but our survey results clearly show that the respondents believed that policies can make a major difference and allow for an expansion of renewables. Although this business case lies primarily in the future, there are policy measures that can make a major difference and allow for an expansion of renewables both in the short- and the long-term perspective. The rentier state literature differentiates the relatively optimistic renewables literature and our survey findings: although it does not contradict the findings that there are beneficial policy solutions, it does suggest that a turn away from fossil fuel export revenue re-distribution through subsidies to a renewables-based energy system is not at all easily implementable and constitutes a path with considerable risks for political stability.

We found two main obstacles to investments in renewables in the GCC, consistently in the literature and the survey. The first is a barrier: the lack of a renewable energy support framework, which-especially when combined with the presence of fossil fuel and energy consumption subsidies - prohibits profitable investments today. This barrier was suggested in the literature as well, as a "super-barrier" preventing profitable investments in renewables.

However, many respondents as well as some conference participants did not believe renewables to be expensive. This belief is confirmed by LCOE calculations (e.g., $[9,10])$ for oil or gas power on the one hand and PV and wind power on the other. This suggests that there may be two ways to make renewable energy investments in the GCC profitable, already in the short term. One way would be to abolish fossil fuel subsides and introduce a market-based pricing mechanism, within which renewables could compete on market conditions, or governments can choose to introduce renewable power support schemes. It may not be necessary to do both, although this is suggested in the bulk of the literature - each of the solutions may suffice on its own. This is important as there are clear advantages and drawbacks to each of the policy solutions, especially in the light of the political economy of rentier states.

Disbanding energy subsidies and creating a level, market-based playing field for fossil fuels and renewables would reduce the strain on public funds and it be an important step towards controlling the demand increase, thus also potentially freeing resources for more lucrative exports. This would, however, need to be done with caution to protect low-income citizens, for example through targeted subsidies or the expansion of existing social safety systems (see [31]). Most significantly, however, removing energy subsidies would also break part of the existing social contract between government 
and population by removing one of the re-distribution channels for fuel export revenues. In particular, it seems difficult — or impossible - to remove subsidies without affecting wealthier and more powerful consumers. Removing subsidies would thus be beneficial for the economy if it works, but carrying them out could thus be politically dangerous for the ruling elite of a rentier state, greatly reducing the attractiveness of this option from their perspective, in particular in the light of the events of the Arab Spring.

A dedicated support scheme for renewables funded by the government would increase the strain on the public budget, but it would not break the social contract of the Gulf rentier states. A government-funded expansion of renewables covering all or a part of the energy demand increase would however free fossil fuel resources for export, thus increasing the available funds: whether this pays off, and how much, is a matter of which renewable energy technology is expanded and what the costs are. Solar PV and wind power, which have lower generation costs than petroleum-fired generation, would, in many cases, reduce the total strain on the state funds.

Alternatively, the consumers could remunerate a renewables support scheme, as they generally do in Europe and elsewhere. However, this could change the way the energy export revenues are re-distributed, by effectively increasing energy prices, thus having similar political dangers to the elites as removing subsidies.

Experiences from other countries show that, although feed-in tariffs have triggered the most renewables expansion (and this is the preferred mechanism of our respondents), the design of the scheme seems more important than which type of scheme is used. Feed-in tariffs, quota systems and investment schemes have triggered investment in many different countries, both in western democracies, such as Germany (a feed-in tariff) and the US (mainly quota schemes), and in more authoritarian systems, such as China (especially feed-in tariffs) [69,70]. All types of support schemes can be complemented with local contents clauses, mandating a certain share of components to be manufactured in the host country - a key issue for the economic diversification effects of a renewables expansion as highlighted by our respondents (see also [26,43]). Which type of scheme is more appropriate for the GCC context is thus mainly a political choice: if implemented well, most renewables support schemes can work.

The second obstacle is both a barrier and a risk: bureaucratic inefficiencies and red tape, which could hinder potentially attractive investment opportunities. This barrier was not suggested as a main obstacle in the specialized GCC renewable energy literature. Our results suggest that improving the efficiency and transparency of the bureaucracy, for example by setting clear and enforceable rules for permission criteria and deadlines for bureaucratic decisions, are key policy measures both to alleviate the bureaucracy barrier and avoid the risk of red tape-caused cost overruns. Importantly, this finding emphasizes that improving the economic environment for renewables is not enough: the bureaucratic processes, in particular generation concessions, permission processes and siting decisions, must be adjusted to accommodate renewable energy projects. Nevertheless, inefficient bureaucracy is a typical characteristic of rentier states: one may thus call for improved institutions and administration, but without a reform of the political system; away from rentierism towards a more diversified economy, this may be difficult.

Furthermore, insufficient awareness about existing investment opportunities was consistently identified in the survey as a serious but relatively easy-to-solve barrier. The respondents do not agree 
that there is a shortage of engineers and know-how in the renewables sector in the GCC, which rejects some of the literature that mentioned this as a possible barrier to a renewable energy expansion. Finally, our respondents do not perceive corruption as a major barrier to investment.

Our findings here indicate a need to go deeper, on a country-by-country basis, to find out exactly what the perceived inefficiencies in the bureaucracy are: are they, for example, because of unclear regulations or rules unsuited for renewables, because the civil servants are not trained for renewables, because dedicated renewable energy institutions are missing, or because fossil fuel interests dominate within the public authorities? Similarly, the question of how to improve the economic case for renewables - by removing subsidies or rather by introducing renewables support schemes - needs to be further researched, on a country-by-country basis, taking into account the political economy of rentier states. The question of how to carry out the desired reform is especially interesting, but also how to design a future, more open domestic energy market. Finally, important future research questions concern the feasibility of the expectations and hopes for job-creation and a renewable technology leadership role for the Gulf countries, as well as the impacts of a large-scale renewables expansion on the traditional energy players, including their ability to continue exporting fossil fuels during and after such an expansion.

Overall, the renewable energy literature, the survey respondents and the participants at the conference in Abu Dhabi give a cautiously positive outlook for renewables in the GCC countries. Right now, the setting is not right, neither concerning the economic framework in place nor concerning regulation and bureaucracy. The long-term potential is vast but the short-term imperative to expand renewables is low, as fossil fuels are still abundant and there are political risks for the elites associated with removing subsidies. On the other hand, in the words of a conference panelist, a great strength of the GCC countries compared to the rest of the world is that they are in no hurry to put in place renewable energy solutions but have the time to think about it and do it the right way and at the right pace. In the past, "the right pace" has been very slow, but there is reason to believe that the future may hold more renewable energies, at least in some countries. We have found here that two main obstacles stand in the way of renewable energy investments, but also that policy can make a difference and, if the political will and capacity for reform is present, trigger a future renewable energy expansion in the GCC countries.

\section{Conclusions}

In this article, we have shown that there is a case and a need for renewable energy in the Gulf Cooperation Countries in the long term, as a way to diversify the economies and prepare for a future in which fossil fuel reserves are being depleted. In the short term, however, investments are deterred by the presence of two obstacles in particular. First, the combination of fossil fuel and electricity consumption subsidies on the one hand and the absence of a dedicated renewable energy support framework on the other make it difficult to profitably invest in renewables in the GCC. Removing energy consumption subsidies could create a more level playing field and enable renewable investments, and it appears particularly beneficial for the overall economic development of the GCC countries. This solution, however, is also particularly difficult to implement, due to the political economy of the rentier states in the Gulf, whose stability is based on redistribution of resource wealth, 
and this is today in part done through energy subsidies. Introducing a support scheme for renewables could increase government expenditure, but it could also be easier to implement in the political setting of the Gulf compared to abandoning consumption subsidies. Second, even if it were possible to make profits from investments in renewables, bureaucratic inefficiencies may cause delays and cost-overruns, or even stop a project altogether. Hence, a support scheme or abolished energy consumption subsidies must be accompanied by increased transparency and efficiency in the bureaucracy, so that potentially attractive investments can obtain the necessary permissions and actually be built.

The potential and the need for renewable energy in the GCC are large, but the administrative and economic environment for renewable energy investments is not right today, and no breakthrough is on the horizon. Reforms will be difficult, as they affect the pillars of the political system, but our results nevertheless show that there is a set of policies that, if implemented, could make a difference and trigger an expansion of renewable energy in the Gulf monarchies in the future.

\section{Supplementary Materials}

Supplementary materials can be accessed at: http://www.mdpi.com/1996-1073/8/8/8263/s1.

\section{Acknowledgments}

Funding for this work came from a European Research Council consolidator grant, contract number 313533. We gratefully acknowledge the assistance of Gus Schellekens in coordinating the incorporation of the survey into the conference session, as well as the other organizers of the conference session for their comments on the survey design and content.

\section{Author Contributions}

Johan Lilliestam and Anthony Patt designed the questionnaire and evaluated the results; Johan Lilliestam did the literature analysis and drafted the article. Johan Lilliestam and Anthony Patt edited and revised the article.

\section{Conflicts of Interest}

The authors declare no conflict of interest.

\section{References}

1. BP Statistical Review of World Energy; BP: London, UK, 2014.

2. Trieb, F. Concentrating Solar Power for the Mediterranean Region; German Aerospace Centre (DLR): Stuttgart, Germany, 2005.

3. BP Statistical Review of World Energy, June 2013; BP: London, UK, 2013.

4. International Energy Agency (IEA). Statistics. Available online: http://www.iea.org/statistics/ statisticssearch/ (accessed on 19 January 2014).

5. Lilliestam, J.; Battaglini, A.; Finlay, C.; Furstenwerth, D.; Patt, A.; Schellekens, G.; Schmidt, P. An alternative to a global climate deal may be unfolding before our eyes. Clim. Dev. 2012, 4, 1-4. 
6. Patt, A.; Komendantova, N.; Battaglini, A.; Lilliestam, J. Regional integration to support full renewable power deployment for Europe by 2050. Environ. Polit. 2011, 20, 727-742.

7. Trieb, F.; Fichter, T.; Moser, M. Concentrating solar power in a sustainable future electricity mix. Sustain. Sci. 2014, 9, 47-60.

8. Trieb, F.; Schillings, C.; Pregger, T.; O’Sullivan, M. Solar electricity imports from the Middle East and North Africa to Europe. Energy Policy 2012, 42, 341-353.

9. Dii. Desert Power 2050; Dii: Munich, Germany, 2012.

10. Dii. Desert Power 2050: Getting Started; Dii: Munich, Germany, 2013.

11. Patt, A. Effective regional energy governance - not global environmental governance - is what we need right now for climate change. Glob. Environ. Change 2010, 20, 33.

12. Ferroukhi, R.; Ghazal-Aswad, N.; Androulaki, S.; Hawila, D.; Mezher, T. Renewable energy in the GCC: Status and challenges. Int. J. Energy Sect. Manag. 2013, 7, 84-112.

13. Erneuerbare Energien in Zahlen. Stand Juni 2013; Bundesministerium für Umwelt, Naturschutz und Reaktorsicherheit (BMU): Berlin, Germany, 2013.

14. Shams Power. Shams Power Company. Available online: http://www.shamspower.ae/en/ (accessed on 19 January 2014).

15. Todorova, V. Dubai launches Dh120m solar power plant. The National. Available online: http://www.thenational.ae/uae/environment/dubai-launches-dh120m-solar-power-plant (accessed on 19 January 2014).

16. Reiche, D. Energy policies of Gulf Cooperation Council (GCC) countries-possibilities and limitations of ecological modernization in rentier states. Energy Policy 2010, 38, 2395-2403.

17. Bhutto, A.W.; Bazmi, A.; Zahedi, G.; Klemeš, J. A review of progress in renewable energy implementation in the Gulf Cooperation Council countries. J. Clean. Prod. 2014, 71, 168-180.

18. Trieb, F. Trans-Mediterranean Interconnection for Concentrating Solar Power; German Aerospace Centre (DLR): Stuttgart, Germany, 2006.

19. Mokri, A.; Ali, M.A.; Emziane, M. Solar energy in the United Arab Emirates: A review. Renew. Sustain. Energy Rev. 2013, 28, 340-375.

20. Hepbasli, A.; Alsuhaibani, Z. A key review on present status and future direction of solar energy studies and applications in Saudi Arabia. Renew. Sustain. Energy Rev. 2011, 15, 5021-5050.

21. Mezher, T.; Dawelbait, G.; Abbas, Z. Renewable energy policy options for Abu Dhabi: Drivers and barriers. Energy Policy 2012, 42, 315-328.

22. Patlitzianas, K.; Doukas, H.; Psarras, J. Enhancing renewable energy in the Arab states of the Gulf: Constraints and efforts. Energy Policy 2006, 34, 3719-3726.

23. Kazem, H. Renewable energy in Oman: Status and future prospects. Renew. Sustain. Energy Rev. 2011, 15, 3465-3469.

24. Al-Badi, A.H.; Malik, A.; Gastli, A. Sustainable energy usage in Oman-opportunities and barriers. Renew. Sustain. Energy Rev. 2011, 15, 3780-3788.

25. Sgouridis, S.; Griffiths, S.; Kennedy, S.; Khalid, A.; Zurita, N. A sustainable energy transition strategy for the United Arab Emirates: Evaluation of options using an integrated energy model. Energy Strategy Rev. 2013, 2, 8-18.

26. Mondal, A.; Khalil, H.S. Renewable Energy Readiness Assessment Report: The GCC Countries; Masdar Institute: Masdar, UAE, 2012. 
27. Moser, M.; Trieb, F.; Fichter, T.; Kern, J. Renewable desalination: A methodology for cost comparison. Desalin. Water Treat. 2013, 51, 1171-1189.

28. Dyllick-Brenzinger, R.; Finger, M. Review of electricity sector reform in five large, oil- and gas-exporting MENA countries: Current status and outlook. Energy Strategy Rev. 2013, 2, 31-45.

29. Charles, C.; Moerenhout, T.; Bridle, R. The Context of Fossil-Fuel Subsidies in the GCC Region and Their Impact on Renewable Energy Development; International Institute for Sustainable Development (IISD): Geneva, Switzerland, 2014.

30. Krane, J. Stability Versus Sustainability: Energy Policy in the Gulf Monarchies; Electricity Policy Research Group, University of Cambridge: Cambridge, UK, 2013.

31. Fattouh, B.; El-Katiri, L. Energy Subsidies in the Arab World; United Nations Development Programme (UNDP): Oxford, UK, 2012.

32. Fattouh, B.; El-Katiri, L. Energy subsidies in the Middle East and North Africa. Energy Strategy Rev. 2013, 2, 108-115.

33. Basedau, M.; Lay, J. Resource curse or rentier peace? The ambiguous effects of oil wealth and oil dependence on violent conflict. J. Peace Res. 2009, 46, 757-776.

34. World Bank. World development indicators. Available online: http://data.worldbank.org/indicator (accessed on 13 February 2015).

35. Mills, R. Sunrise in the Desert; PricewaterhouseCoopers (PwC), Emirates Solar Industry Association (ESIA): Abu Dhabi, UAE, 2012.

36. Charabi, Y.; Al-Badi, A. Creating an enabling environment for renewable energy application in the Sultanate of Oman. Int. J. Green Energy 2015, 12, 1169-1177.

37. IRENA. Concentrating Solar Power; International Renewable Energy Agency (IRENA): Abu Dhabi, UAE, 2012.

38. League of Arab States. Pan-Arab Renewable Energy Strategy 2030; League of Arab States: Cairo, Egypt, 2014.

39. Erneuerbar Beschäftigt; German Federal Ministry for the Environment (BMU): Berlin, Germany, 2013.

40. Lilliestam, J.; Blumer, Y.; Geddes, A.; Labordena, M.; Späth, L.; van Vliet, O. More than costs: On the fit between solar and renewable electricity policy motivations and energy system models. In Solar Power: Technologies, Environmental Impacts and Future Prospects; Bailey, S., Ed.; Nova: Hauppage, NY, USA, 2014; pp. 23-56.

41. Schmidt, P.; Lilliestam, J.; Fürstenwerth, D.; Battaglini, A. Electricity for growth and jobs in Tunisia: Exploring the nuclear and renewable electricity options. In Tunisia: Economic, Political and Social Issues; Pusatieri, M., Cannamela, J., Eds.; Nova: Hauppage, NY, USA, 2012; pp. 31-61.

42. Komendantova, N.; Patt, A. Employment under vertical and horizontal transfer of concentrated solar power technology to North African countries. Renew. Sustain. Energy Rev. 2014, 40, 1192-1201.

43. Bryden, J.; Riahi, L.; Zissler, R. MENA Renewables Status Report 2013; Renewable Energy Policy Network for the 21st century (REN21): Paris, France, 2013.

44. Global Employment Trends 2014; International Labour Organization (ILO): Geneva, Switzerland, 2014.

45. O’Sullivan, A.; Rey, M.-E.; Mendez, J.G. Opportunities and Challenges in the MENA Region; Organisation for Economic Co-operation and Development (OECD): Vienna, Austria, 2011. 
46. Rethinking Arab Employment; World Economic Forum (WEF): Davos, Switzerland, 2014.

47. Castro, P.; Hörnlein, L.; Michaelowa, K. Constructed peer groups and path dependence in international organizations: The case of the international climate change negotiations. Glob. Environ. Change 2014, 25, 109-120.

48. Switch on the Lights-Unlocking the UAE's Solar Potential; Price water house Coopers (PwC), Emirates Solar Industry Association (ESIA): Abu Dhabi, UAE, 2012.

49. Al-Hatmi, Y.; Tan, C.; Al-Badi, A.; Charabi, Y. Assessment of the conciousness levels on renewable energy resources in the Sultanate of Oman. Renew. Sustain. Energy Rev. 2014, 40, 1081-1089.

50. Al-Saleh, Y. Renewable energy scenarios for major oil-producing nations: The case of Saudi Arabia. Futures 2009, 41, 650-662.

51. Ross, M. A closer look at oil, diamonds and civil war. Annu. Rev. Polit. Sci. 2006, 9, 265-300.

52. Eisgruber, L. The resource curse: Analysis of the applicability to the large-scale export of electricity from renewable sources. Energy Policy 2013, 57, 429-440.

53. Bjorvatn, K.; Naghavi, A. Rent seeking and regime stability in rentier states. Eur. J. Polit. Econ. 2011, 27, 740-748.

54. Beblawi, H. The Rentier State in the Arab World. In The Arab State; Luciani, G., Ed.; Routledge: London, UK, 1990; pp. 85-98.

55. Hassanzadeh, E. Recent Developments in Iran's Energy Subsidy Reforms; International Institute for Sustainable Development (IISD): Geneva, Switzerland, 2012.

56. Farajzadeh, Z; Bakhshoodeh, M. Economic and environmental analyses of Iranian energy subsidy reform using computable general equilibrium (CGE) model. Energy Sustain. Dev. 2015, 27, 147-154.

57. Collins, R.; Gowharji, W.; Habib, A.; Alwajeeh, R.; Connors, S.; Alfaris, A. Evaluating scenarios of capacity expansion given high seasonal variability of electricity demand: The case of Saudi Arabia. In Proceedings of the 31st International Conference of the System Dynamics Society, Cambridge, MA, USA, 21-25 July 2013.

58. Muirhead, J. Part three: CSP vs PV in Saudi Arabia-meeting the demand curve and satisfying the need for economic development. CSP Today. Available online: http://social.csptoday.com/markets/ part-three-csp-vs-pv-saudi-arabia---meeting-demand-curve-and-satisfying-need-economic-develo (accessed on 22 February 2015).

59. Pfenninger, S.; Gauché, P.; Lilliestam, J.; Damerau, K.; Wagner, F.; Patt, A. Potential for concentrating solar power to provide baseload and dispatchable power. Nat. Clim. Change 2014, 4, 689-692.

60. Patt, A.; Pfenninger, S.; Lilliestam, J. Vulnerability of solar energy infrastructure and output to climate change. Clim. Change 2013, 121, 93-102.

61. Lilliestam, J. Vulnerability to terrorist attacks in European electricity decarbonisation scenarios: Comparing renewable electricity imports to gas imports. Energy Policy 2014, 66, 234-248.

62. Lilliestam, J.; Ellenbeck, S. Fostering interdependence to minimise political risks in a European-North African renewable electricity Supergrid. Green 2012, 2, 105-109.

63. Komendantova, N.; Patt, A.; Barras, L.; Battaglini, A. Perception of risks in renewable energy projects: The case of concentrated solar power in North Africa. Energy Policy 2012, 40, 254-259. 
64. Komendantova, N.; Pfenninger, S.; Patt, A. Governance barriers to renewable energy in North Africa. Int. Spect. 2014, 49, 50-65.

65. Edelman. Trust in Energy. Available online: http://www.edelman.com/insights/intellectual-property/ 2014-edelman-trust-barometer/trust-in-business/trust-energy/ (accessed on 19 March 2014).

66. Lehmann, P.; Gawel, E. Why should support schemes for renewable electricity complement the EU emissions trading scheme? Energy Policy 2013, 52, 597-607.

67. Verbruggen, A.; Lauber, V. Assessing the performace of renewable electricity support instruments. Energy Policy 2012, 45, 635-644.

68. Bergek, A.; Jacobsson, S. Are tradable green certificates a cost-efficient policy driving technical change or a rent-generating machine? Lessons from Sweden 2003-2008. Energy Policy 2010, 38, 1255-1271.

69. Labordena, M.; Lilliestam, J. Cost and transmission requirements for reliable solar electricity from deserts in China and the United States. Energy Procedia 2015, in press.

70. Renewables 2015; Renewable Energy Policy Network for the 21st century (REN21): Paris, France, 2015.

(C) 2015 by the authors; licensee MDPI, Basel, Switzerland. This article is an open access article distributed under the terms and conditions of the Creative Commons Attribution license (http://creativecommons.org/licenses/by/4.0/). 